\title{
Efek Ekor Jas dan Identifikasi Partai Politik dalam Pemilu Serentak 2019 di Bali
}

\author{
Kadek Dwita Apriani \\ Program Doktor IImu Politik Universitas Indonesia \\ Email: kadek88@gmail.com
}

\begin{abstract}
This study is to see the effect of tail suits on the political choices of Balinese people who are known to have the highest identification of political parties in Indonesia ahead of simultaneous elections (pemilu serentak) in 2019. The method used is quantitative research methods with 1,120 respondents spreading across all regenciess/cities in Bali. The sampling technique applied was multistage random sampling, so the margin of error was $3 \%$. The results of this study indicate the tail coat effect present in the community which has a strong identification of political parties. It's just that the tail coat effect reads smaller than ID party in the political choices of the Balinese people.
\end{abstract}

Keywords: tailcoat effect, identification of political parties, simultaneous election 2019.

\section{PENDAHULUAN}

Bali merupakan wilayah yang secara politik sering diidentifikasi sebagai basis PDIP (Partai Demokrasi Indonesia Perjuangan) sejak runtuhnya Orde Baru. Hal ini terbaca dari berbagai momentum elektoral yang pernah terselenggara. Dari hasil pemilu 2014, PDIP berhasil mendudukkan kadernya sebagai ketua DPRD di hampir seluruh kabupaten/kota di Bali. Hal serupa terjadi pada kekuasaan eksekutif. Dalam beberapa pilkada serentak di Bali, kandidat yang diusung partai ini berhasil memenangkan Pilkada. Saat ini tercatat tujuh dari Sembilan kepala daerah kabupaten/kota di Bali merupakan kandidat yang diusung PDIP.

Beberapa penelitian sebelumnya menyebutkan bahwa fenomena ini disebabkan oleh adanya identifikasi partai politik atau party ID yang kuat dari pemilih di Bali terhadap PDIP. Identifikasi partai merupakan ikatan psikologis yang stabil antara pemilih dengan partai politik tertentu, sehingga pemilih yang memilikinya tidak lagi dipengaruhi oleh faktor jangka pendek dalam menentukan pilihan politiknya.

Pada tahun 2013, sebuah penelitian ilmiah yang dipublikasi dalam jurnal nasional menyebutkan bahwa pemilih dengan identifikasi partai politik di Indonesia hanya tersisa $14,3 \%$. Menariknya dalam penelitian itu disebutkan adanya satu wilayah di Indonesia yang memiliki Party ID jauh di atas rata-rata nasional. ${ }^{1}$ Wilayah yang dimaksud adalah Bali. Hanya saja penelitian tersebut telah dilakukan enam tahun silam. Sangat penting untuk melihat perkembangan dari temuan mengenai party ID di

\footnotetext{
${ }^{1}$ Burhanuddin Muhtadi, "Politik Uang dan Dinamika Elektoral di Indonesia: Sebuah Kajian Awal Interaksi Antara Party ID dan Patron Klien" dalam Jurnal Penelitian Politik, (Vol 10, No 1, Juni 2013), hlm. 51.
} 
Bali mengingat adanya beberapa fenomena yang muncul belakangan menjelang pemilu serentak 2019.

Momentum ini adalah kali pertama Indonesia menyelenggarakan pemilu legislatif dan pemilu presiden secara bersamaan. Hal ini diduga akan melahirkan efek ikutan yang berpengaruh bagi partai politik. Dalam berbagai tulisan para pengamat dan ahli politik menjelang pemilu 2019 disebutkan mengenai coattail effect. Coattail effect adalah istilah yang merujuk pada suatu tindakan yang menimbulkan pengaruh pada tindakan lain (pengaruh ikutan). Dalam terjemahan bebas diartikan sebagai efek kibasan buntut jas. Calon pemimpin yang diusung memiliki buntut jas terhadap elektabilitas suara pada partai pengusung nantinya. Karena pemilihan presiden bersamaan dengan pemilihan anggota legislatif, maka tentunya pilihan rakyat terhadap pasangan capres dan cawapres tidak jauh dari calon anggota dewan dari partai pengusungnya. ${ }^{2}$

Jika melihat dua hal di atas maka dapat dikatakan, identifikasi partai politik menjelaskan bahwa pemilih memilih kandidat berdasarkan partai pengusungnya, sedangkan coattail effect menjelaskan bahwa partai memperoleh benefit elektoral dari calon presiden yang diusungnya. Pada akhirnya sangat menarik melihat kedua konsep ini menjelang 2019 di Bali karena Bali merupakan wilayah dengan identifikasi partai politik yang kuat yang juga turut melaksanakan pemilu serentak, sehingga dapat dilihat bagaimana kedua factor ini saling berinteraksi. Oleh karena itu, pertanyaan penelitian yang ingin dijawab melalui penelitian ini adalah bagaimana identifikasi partai politik masyarakat Bali menjelang pemilu serentak 2019? Apakah coattail effect terjadi dalam masyarakat yang memiliki identifikasi partai politik seperti Bali? Bagaimana akibat dari kehadiran coattail effect dalam masyarakat yang memiliki identifikasi partai politik?

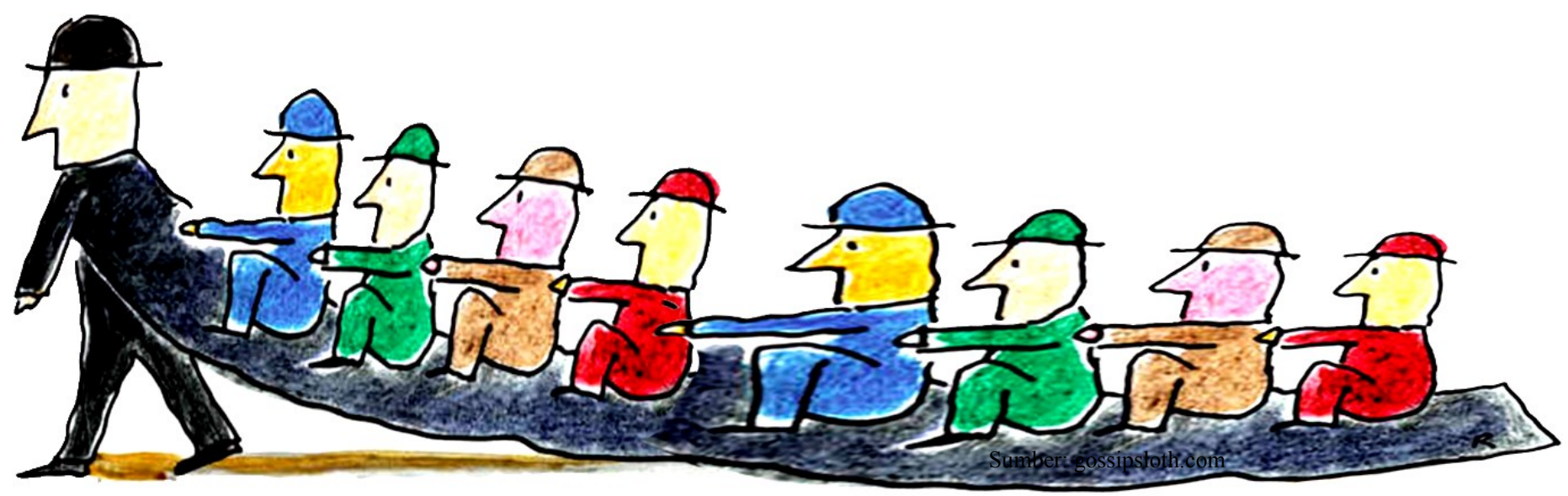

\section{LANDASAN TEORI}

Dalam menjawab pertanyaan penelitian yang telah dikemukakan di atas, akan digunakan dua teori utama, yaitu teori identifikasi partai politik dan teori coattail effect (teori efek ekor jas).

\section{Teori Identifikasi Partai Politik}

Konsep identifikasi seperti yang dikutip Mujani dari Campbell adalah "orientasi afeksi individu terhadap kelompok penting dalam masyarakat". Oleh karena itu, definisi

2 Samsuddin Harris dkkm Pemilu Nasional Serentak, (Jakarta, LIPI, 2015), hlm. 22. 
konseptual dari identifikasi partai (Party ID) adalah orientasi afeksi, atau perasaan seseorang terhadap partai politik. Party ID dipercaya memiliki pengaruh yang kuat dan luas pada sikap politik. Dalam hal ini Party ID merupakan faktor independen dalam menjelaskan sikap dan perilaku politik. ${ }^{3}$

Identifikasi partai merupakan ikatan psikologis yang stabil antara pemilih dengan partai politik tertentu, sehingga pemilih yang memilikinya tidak lagi dipengaruhi oleh faktor jangka pendek dalam menentukan pilihan politiknya. Identifikasi partai merupakan komponen psikologis yang memberi sumbangan bagi stabilitas dukungan terhadap partai politik. Identitas partai politik berada pada tingkat sikap atau orientasi, bukan pada tindakan atau perilaku. ${ }^{4}$

Party ID awalnya muncul di Amerika Serikat yang menggunakan sistem dua partai (Demokrat dan Republik). Jika seseorang mengidentifikasikan dirinya lebih dekat dengan Demokrat maka yang bersangkutan dapat dipastikan akan memilih calon presiden yang diusung oleh partai Demokrat, demikian juga dengan kaum republikan yang cenderung memilih calon pemimpin yang diusung partainya. ${ }^{5}$ Dengan demikian, dapat dikatakan bahwa teori ini melihat sikap politik para pemberi suara relatif menetap dari pemilu ke pemilu. Pemilih dipandang tidak terpengaruh oleh komunikasi politik pada saat atau menjelang kampanye politik.

Identifikasi partai dilandasi oleh konsep sikap dan sosialisasi. Sikap seseorang sangat mempengaruhi perilaku politiknya. Sikap itu terbentuk melalui proses yang berlangsung lama, bahkan sejak seorang pemilih masih berusia dini. Pada usia dini, seorang calon pemilih telah menerima pengaruh politik dari orang tuanya, baik dalam bentuk komunikasi langsung atau pandangan politik yang diekspresikan orang tuanya. Proses sosialisasi yang panjang itulah yang membentuk ikatan yang kuat antara pemilih dan sebuah partai politik. Dengan kata lain, Identifikasi partai sering kali diwariskan dari orang tua pada anak-anak mereka. Seiring bertambahnya usia, identifikasi partai menjadi bertambah stabil dan intensif. Identifikasi partai merupakan orientasi yang permanen dan tidak berubah dari pemilu ke pemilu. Identifikasi partai hanya dapat berubah jika seseorang mengalami perubahan pribadi yang besar atau situasi politik yang luar biasa.

Teori ini disebut sangat khas Amerika Serikat karena lahir dengan latar belakang sistem politik negara tersebut. Oleh karenanya, pengukuran yang paling awal digunakan untuk melihat faktor ini bersifat unidimensional, apakah pemilih

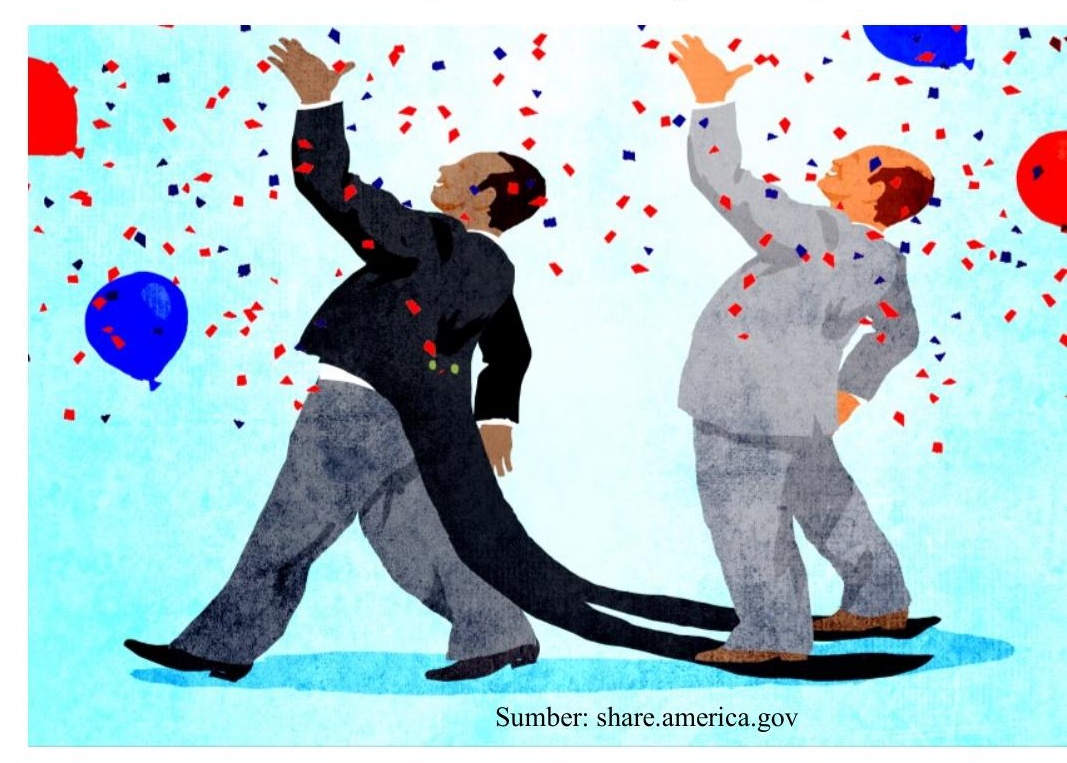

3 Saiful Mudjani dkk, Kuasa Rakyat: Analisis tentang Perilaku Memilih dalam Pemilihan Legislatif dan Presiden Indonesia Pasca-Orde Baru (Jakarta: Mizan, 2011), hlm. 374.

${ }^{4}$ Ibid.

${ }^{5}$ Donald Green et. al., Partisan Heart and Mind: Political Parties and Social Identities of voters, (London: Yale University Press, 2002), hlm. 27. 
menganggap dirinya seorang Republican atau Democrat. Namun pengukuran semacam itu mengandaikan sebuah sistem kepartaian yang sederhana (dua partai) dan sulit diaplikasikan pada sistem multipartai. Modifikasi atas pengukuran tersebut diajukan oleh beberapa studi setelahnya untuk melihat Party ID pada sistem kepartaian yang lebih kompleks. ${ }^{6}$ Dalam sistem multi partai, Party ID diukur dengan "apakah merasa lebih dekat dengan partai politik tertentu?" cara pengukuran tersebut telah digunakan oleh Mudjani dkk (2011); Burhanuddin Muhtadi (2018) untuk mengukur Party ID di Indonesia.

Para ilmuan Eropa juga tak ketinggalan melakukan serangkaian studi yang hasilnya menemukan bahwa Party ID tidak terlalu signifikan di Eropa sejak tahun 1970an. ${ }^{7}$ Hal ini disebabkan karena masyarakat AS berbeda dengan masyarakat Eropa. Di Eropa, pemilih dikatakan lebih memiliki afiliasi dengan kelas sosial dan agamanya. Meski memang teori identifikasi partai politik dalam perilaku memilih mendapat banyak kritik terutama ketika diterapkan dalam konteks masyarakat di luar Amerika Serikat, namun perspektif ini tetap digunakan dalam melihat fenomena perilaku memilih di negara-negara lain seperti di Indonesia.

Temuan Mujani dkk memperlihatkan Party ID pemilih Indonesia mengalami dinamika dari pemilu ke pemilu sejak tahun 1999 hingga tahun 2014. Pada tahun 1999 sekitar $86 \%$ pemilih Indonesia mengidentifikasi diri dengan partai tertentu. ${ }^{8}$ Kemudian pengukuran berikutnya dilakukan pada tahun 2001 dan diperoleh angka yang jauh berbeda. Pada tahun 2001, pemilih yang merasa dekat dengan partai tertentu atau memiliki party ID hanya tersisa 33\%. Setahun menjelang pemilu 2004, angka pemilih dengan party ID menjadi 55\%. Mengalami peningkatan cukup signifikan dari dua tahun sebelumnya. Setelah pemilu 2004, penurunan jumlah pemilih dengan party ID di Indonesia kembali terjadi. Pada tahun 2005, hasil survei yang disajikan dalam buku Mujani dkk memperlihatkan pemilih dengan party ID di Indonesia tersisa 30\%. Angka tersebut terus menurun hingga menjelang pemilu 2009. Pada tahun pemilu tersebut, jumlah pemilih yang memiliki party ID tinggal 18\%. Indikasi menurunnya party ID kembali terjadi menjelang pemilu 2014. Pada tahun 2014, pemilih di Indonesia yang masih merasa dekat dengan partai politik hanya tersisa $14 \% .^{9}$

\section{Teori Efek Ekor Jas}

Efek ekor jas atau coattail effect secara umum merujuk pada kecenderungan kandidat popular dalam satu level pemerintahan dapat menyebabkan pemilih memilih kandidat dari partai yang sama dengan kandidat populer tersebut untuk level pemerintahan yang lain. ${ }^{10}$ Terdapat beberapa varian dari coattail effect. Setidaknya Zudenkova dalam karyanya menyebutkan dua istiah, yakni presidential coattail effect dan reverse coattail effect.

\footnotetext{
${ }^{6}$ Saiful Mujani dkk, 2011, Op.Cit., hlm. 377.

7 Jacques Thomassen (ed), The European Voter: A Comparative Study of Modern Democracies, (New York: Oxford University Press, 2005), hlm. 12.

${ }^{8}$ Saiful Mujani dkk, Voting Behavior in Indonesia Since Democratization: Critical Democrats, (United Kingdom: Cambridge University Press, 2018), hlm. 187.

$9 \mathrm{lbid}$., hlm. 188.

10 Galina Zudenkova, A Political Agency Model of Coattail Voting, MPRA Paper No. 28800, February 2011, https://mpra.ub.uni-muenchen.de/28800/1/MPRA paper 28800.pdf hlm. 2
} 
Istilah pertama yakni Presidential coattail effect, merupakan kondisi dimana anggota legislatif dari partai tertentu dipilih oleh pemilih karena performa dari pemerintahannya (presiden). ${ }^{11}$ Sedangkan istilah kedua, reverse coattail effect adalah kondisi dimana seorang kandidat popular pada level yang lebih rendah dapat meningkatkan perolehan suara partainya pada level pemerintahan yang lebih tinggi. ${ }^{12}$

Two-sided coattail effects therefore arise. On the one hand, the executive's performance afects the congress member's reelection, which gives rise to a presidential coattail effect. On the other hand, the executive's reelection depends on the congress member's performance, which results in a reverse coattail effect. ${ }^{13}$

Penjelasan mengenai definisi coattail effect yang kurang lebih mirip dengan penjelasan Zudencova (2011), dikemukakan oleh Marc Meredith. Coattail effect digambarkan olehnya sebagai berikut:

A coattail effect occurs when an individual who would usually support a downballot candidate from party $A$ instead votes for the down-ballot candidate from party $B$ because he or she supports the top-ballot candidate from party $B$. One potential explanation for such behavior is that people generally dislike holding conflicting beliefs, such as simultaneously supporting Democratic and Republican candidates. As such, voters may prefer to cast down-ballot votes for candidates from the party of their preferred top-ballot candidate. Ballot features may also encourage voters to cast straight-ticket ballots and support the party of their preferred top-ballot candidate in down-ballot elections. ${ }^{14}$

Secara jelas Meredith menyebutkan bahwa coattail effect merujuk pada gambaran dimana pemilih yang biasanya (pada pemilu-pemilu sebelumnya) memilih partai Auntuk level yang lebih rendah berubah pilihan menjadi partai B karena ia mendukung kandidat dari partai B pada level yang lebih tinggi.

\section{METODOLOGI}

Penelitian ini adalah penelitian kuantitatif berjenis deskriptif karena penelitian ini bertujuan untuk memberi gambaran mengenai identifikasi partai politik dan efek ekor jas pada masyarakat Bali menjelang pemilu serentak 2019. Penelitian ini mengambil sampel sebanyak 1.120 yang tersebar di seluruh kabupaten/kota di Bali. Margin of error dalam penelitian ini sebesar 2,5\%. Teknik sampling yang digunakan adalah multistage random sampling seperti yang dapat dilihat dalam bagan berikut.

\footnotetext{
11 Ibid.

12 Ibid, hlm. 2-3

$13 \mathrm{lbid}$. hlm 3

${ }_{14}$ Marc Meredith, Exploiting Friends-and-Neighbors to Estimate Coattail Effects, Maret 2013, https://www.sas.upenn.edu/ marcmere/workingpapers/FriendsAndNeighbors.pdf, hlm. 3-4
} 


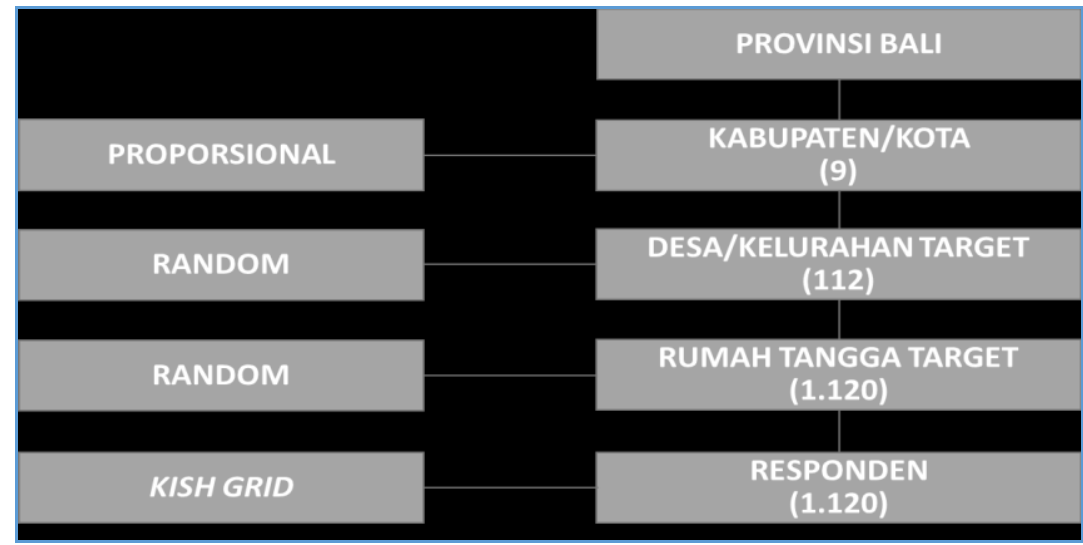

Pengambilan data dilakukan dengan wawancara tatap muka menggunakan kuesioner. Data diambil menjelang pemilu serentak 2019, tepatnya pada bulan Februari hingga Maret 2019.

Sebelum menjelaskan lebih jauh mengenai temuan penelitian tentang identifikasi partai politik dan efek ekor jas yang terjadi menjelang pemilu 2019 di Bali, penting untuk melihat profil responden dalam penelitian ini. Hal ini untuk memastikan bahwa karakteristik populasi sama dengan karakteristik sampel yang diambil. Jika melihat jenis kelamin pemilih dalam Daftar Pemilih Tetap di provinsi Bali, maka diketahui bahwa perbandingan pemilih laki-laki dan perempuan adalah 49,5\% berbanding $50,5 \%$. Oleh sebab itu dalam survei ini perimbangan gender tersebut dijaga di tangka 50:50 seperti yang diperlihatkan pada gambar 1.

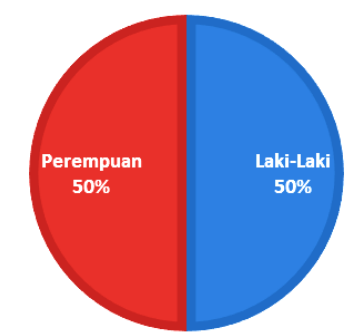

Gambar 1: Gender Responden

Selanjutnya untuk tingkat Pendidikan responden, paling banyak responden berada pada tingkat Pendidikan SMA atau sederajat (43\%) dan disusul oleh responden dengan tingkat Pendidikan SD atau sederajat. Data mengenai hal tersebut dapat dilihat dalam gambar 2 .

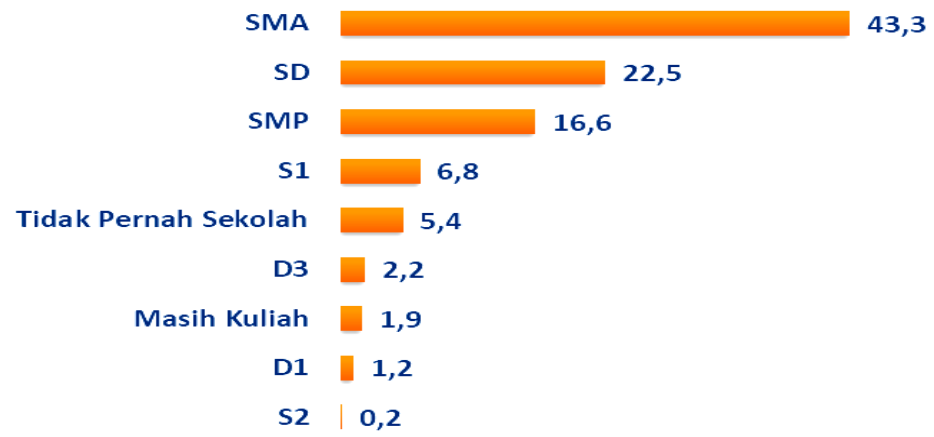

Gambar 2: Pendidikan yang Ditamatkan oleh Responden 
Data tersebut di atas tidak jauh berbeda dengan data BPS provinsi Bali mengenai karakteristik penduduk Bali yang berusia lebih dari 15 Tahun dari aspek Pendidikan. Data tersebut menyebutkan bahwa masyarakat Bali paling banyak berada pada tingkat pedidikan SMA dan SD. ${ }^{15}$ Hal ini memperlihatkan bahwa sampel dalam penelitian ini mewakili populasi Bali.

Untuk penghasilan rata-rata masyarakat Bali paling banyak berada pada angka dua hingga tiga juta per bulan, kemudian disusul dengan masyarakat yang berpenghasilan Rp. 1.500 .000 hingga Rp. 2.000.000. data mengenai penghasilan rata-rata responden per bulannya ditunjukkan dalam gambar 3 .

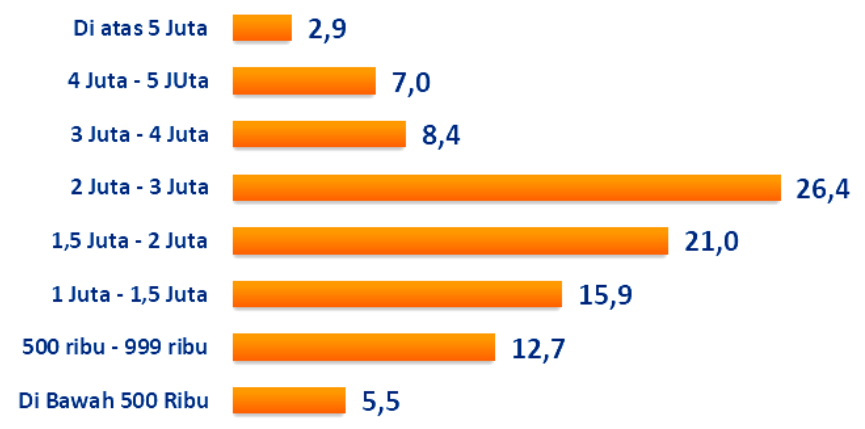

Gambar 3: Penghasilan rata-rata responden per bulan

Tiga data di atas menjelaskan bahwa responden dalam penelitian ini dapat dikatakan telah mewakili populasi pemilih di Bali secara keseluruhan pada tahun 2019. Hal ini penting dijelaskan agar pembaca dapat memahami bahwa data persepsional yang muncul pada bagian berikutnya diambil dari populasi pemilih Bali.

\section{IDENTIFIKASI PARTAI POLITIK DAN EFEK EKOR JAS DALAM MASYARAKAT BALI MENJELANG PEMILU SERENTAK 2019}

Pada bagian terdahulu disebutkan bahwa identifikasi partai politik umumnya diukur dengan melihat perasaan kedekatan pemilih dengan partai tertentu. Pengukuran terakhir atas hal tersebut di Bali terakhir dilakukan dan dipublikasikan pada tahun 2013. Hasil dari penelitian tahun 2013 hanya menyebutkan bahwa rata-rata pemilih di Indonesia yang masih memiliki identifikasi partai politik adalah 14\%, sedangkan di Bali angka pemilih dengan identifikasi partai jauh di atas angka rata-rata nasional. Penulis temuan tersebut tidak menyebutkan angka pasti, sehingga sangat sulit untuk membuat perbandingan dari temuan tersebut setelah enam tahun berlalu.

Temuan survei di Bali pada akhir tahun 2018 dan awal tahun 2019 menunjukkan bahwa jumlah pemilih di Bali yang mengidentifikasi diri dengan partai politik tertentu berada pada kisaran $24 \%$. Angka tersebut jika dibandingkan dengan rata-rata nasional yang disebutkan dalam karta Mujani atau Muhtadi (14\%) memang jauh lebih tinggi. Salah satu dampak dari kehadiran identifikasi partai politik dalam satu masyarakat adalah konsistensi pilihan politik masyarakatnya.

Dalam teori tentang identifikasi partai politik telah dikemukakan bahwa pendekatan ini memandang pilihan politik pemilih cenderung tetap dan tidak terpengaruh oleh komunikasi politik karena identifikasi partai politik sering kali

${ }^{15}$ BPS Provinsi Bali, Provinsi Bali dalam Infografis 2017, (Bali: BPS Provinsi Bali, 2018), hlm. 9 
merupakan warisan dari orang tua pada anaknya dan berkaitan sangat erat dengan sosialisasi politik di tingkat terkecil. Untuk melihat bagaimana ketetapan pilihan politik masyarakat Bali dapat dilihat dari pilihan partai politik pemilih pada pemilu 2014 dan pemilu 2019. Data mengenai hal ini tercermin dalam gambar 4.

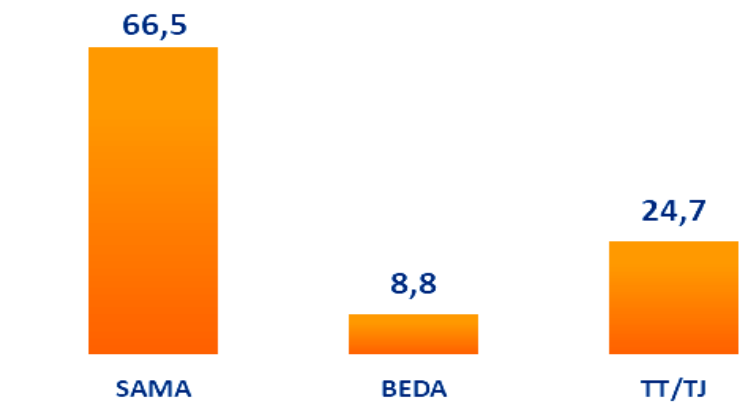

Gambar 4: Apakah Anda Memilih Partai Politik yang Sama dalam Pemilu 2014 dan 2019?

Temuan survei pada bulan Maret 2019 di provinsi Bali memperlihatkan, pada pemilu 2019 sebanyak 66,5\% pemilih Bali mengaku akan memilih partai politik yang sama dengan partai politik pilihannya pada pemilu 2014 . Hanya ada sekitar $8,8 \%$ pemilih Bali yang mengaku akan memilih partai politik yang berbeda dari pilihan partai pada pemilu sebelumnya. Sebanyak $24,7 \%$ sisanya menyatakan tidak tahu dan tidak menjawab. Sebagian besar dar yang tidak menjawab adalah pemilih yang belum memiliki hak pilih pada pemilu 2014 lalu.

Temuan dari survei di Bali tahun 2019 ini menunjukkan bahwa jumlah pemilih Bali yang memiliki identifikasi partai politik lebih tinggi di banding angka rata-rata nasional. Jumlah pemilih di Bali dengan pilihan partai yang menetap (sama antara pemilu 2014 dan 2019) cukup besar, bahkan di atas 65\%. Konsistensi pilihan partai politik pemilih di Bali pada tahun 2019 juga dapat dilihat pada data mengenai alasan pemilih memilih partai politik dalam pemilu 2019. Data mengenai alasan pemilih tersebut disajikan dalam Gambar 5. Alasan pemilih memilih partai politik tertentu di Bali paling banyak karena dari dulu telah memilih partai yang bersangkutan (13,8\%). Hal tersebut mengkonfirmasi adanya ketetapan pilihan politik dalam masyarakat Bali. Ketetapan pilihan tersebut secara teoritis disebut berhubungan dengan identifikasi partai politik.

Data terkait dengan alasan pemilih memilih partai politik tertentu juga dapat dipergunakan untuk melihat coattail effect dalam pemilu serentak 2019 di Bali. Pada gambar 5 di bawah ini diperlihatkan bahwa alasan pada urutan kedua dan ketiga, setelah "dari dlu memilih partai tersebut" yang menyebabkan masyarakat Bali memilih partai tertentu adalah suka dengan calegnya (10,9\%) dan merupakan partai pendukung pemerintahan presiden Joko Widodo (8,6\%). 


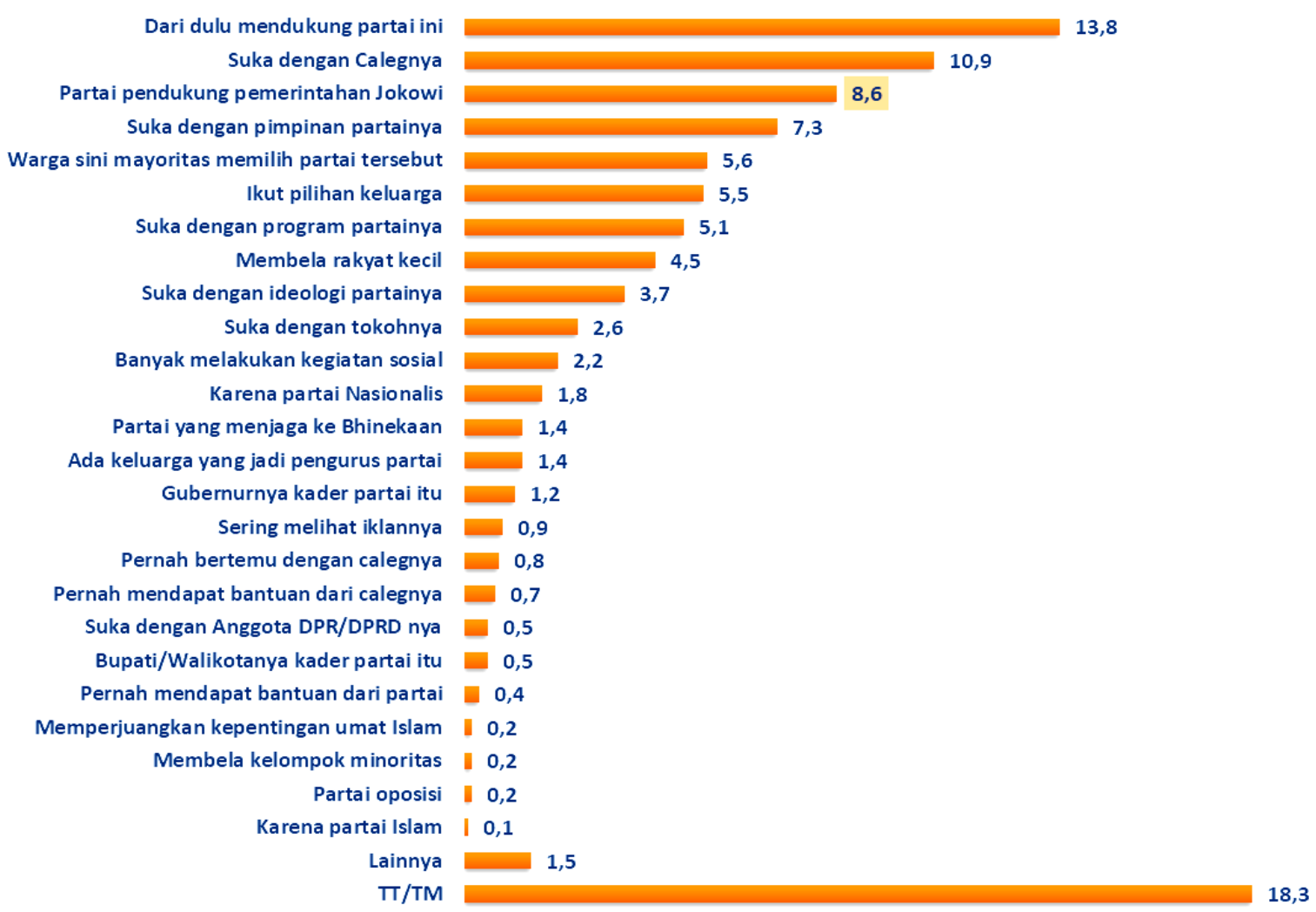

Gambar 5: Alasan Memilih Partai dalam Pemilu 2019

Dua alasan tersebut di atas mencerminkan reverse dan presidential coattail effect. Lebih jauh data di atas dapat diinterpretasikan bahwa dua varian coattail effect hadir dalam masyarakat Bali menjelang Pemilu 2019. Efek ekor jas dari presiden Joko Widodo di Bali berada pada kisaran 8,6\%, karena sebesar 8,6\% pemilih menyebutkan memilih partai politik dalam pemilu 2019 dengan alasan merupakan partai pendukung pemerintahan Jokowi. Sementara itu efek ekor jas yang diperoleh partai dari mencalonkan kandidat yang disukai pemilih Bali, sebesar 10,9\%.

Dengan begitu, faktor identifikasi partai politik dan efek ekor jas merupakan dua hal yang paling penting untuk menjelaskan perolehan suara partai politik di Bali pada pemilu tahun 2019. Faktor-faktor perilaku memilih lainnya seperti faktor-faktor sosiologis yang sebelumnya diyakini membawa pengaruh besar bagi pilihan politik masyarakat dengan karakteristik tradisional seperti Bali, kini tidak terlalu menonjol.

\section{PENUTUP}

Pemilu serentak yang baru pertama kali dilaksanakan di Indonesia pada tahun 2019 disinyalir akan memperkuat kehadiran efek ekor jas bagi partai politik secara nasional, dimana partai politik akan mendapat benefit electoral dari pasangan calon presiden dan wakil presiden yang diusungnya. Hal ini bisa hadir karena pemilih Indonesia secara umum dinilai tidak memiliki identifikasi partai politik. Jikapun ada yang memiliki identifikasi partai politik, jumlahnya sangat kecil dan lemah.

Fakta nasional itu agak berbeda dengan kecenderungan karakteristik pemilih Bali. Pemilih Bali yang memiliki identifikasi partai politik sebanyak $24 \%$. Angka tersebut 
jauh di atas angka party ID nasional yang berada di kisaran 14\%. Selain kuantitas, kualitas party ID di Bali juga cukup baik. Hal ini terlihat dari konsistensi pilihan politik pemilih di wilayah ini lebih dari $65 \%$. Setelah diketahui karakteristik politik masyarakat Bali, ingin dilihat bagaimana efek ekor jas dalam pemilu serentak terhadap pilihan politik masyarakat yang telah memiliki party ID seperti di Bali.

Temuan survei yang dijelaskan pada bagian pembahasan di atas menunjukkan bahwa coattail effect atau efek ekor jas juga hadir dalam masyarakat yang memiliki party ID seperti Bali. Data dari hasil survei memperlihatkan bahwa alasan memilih yang dikemukakan pemilih di Bali lebih banyak terkait dengan party ID dibandingkan presidential dan reverse coattail effect.

\section{DAFTAR PUSTAKA}

BPS Provinsi Bali. 2018. Provinsi Bali dalam Infografis 2017. Bali: BPS Provinsi Bali.

Green, Donald dkk. 2002, Partisan Heart and Mind: Political Parties and Social Identities of voters, London: Yale University Press.

Harris, Samsuddin dkk. 2015. Pemilu Nasional Serentak. Jakarta: LIPI.

Meredith, Marc. 2013. "Exploiting Friends-and-Neighbors to Estimate Coattail Effects", Maret, https://www.sas.upenn.edu/ marcmere/workingpapers/FriendsAndNeighbors.pdf.

Mudjani, Saiful dkk. 201. Kuasa Rakyat: Analisis tentang Perilaku Memilih dalam Pemilihan Legislatif dan Presiden Indonesia Pasca-Orde Baru. Jakarta: Mizan.

Mujani, Saiful dkk. 2018. Voting Behavior in Indonesia Since Democratization: Critical Democrats, United Kingdom: Cambridge University Press.

Muhtadi, Burhanuddin. 2013. "Politik Uang dan Dinamika Elektoral di Indonesia: Sebuah Kajian Awal Interaksi Antara Party ID dan Patron Klien" dalam Jurnal Penelitian Politik, Vol 10, No 1, Juni.

Thomassen, Jacques (ed). 2005. The European Voter: A Comparative Study of Modern Democracies, New York: Oxford University Press.

Zudenkova, Galina. 2011. A Political Agency Model of Coattail Voting, MPRA Paper No. 28800, February. https://mpra.ub.uni-muenchen.de/28800/1/MPRA paper 28800.pdf. 